\title{
En sak i taget? \\ Om specialisering inom \\ socialtjänstens individ- och \\ familjeomsorg
}

\section{ÅKE BERGMARK \& TOMMY LUNDSTRÖM}

Hur det sociala arbetet $i$ kommunerna skall organiseras tycks ständigt vara föremål för omvärderingar - omorganisering verkar vara mer regel än undantag. Med data från hundra svenska kommuner och med utgångspunkt frän begreppet specialisering diskuteras i denna artikel organisationsförändringarnas inriktning och omfattning.

\section{Inledning $^{1}$}

En företeelse som alla som arbetar inom socialtjänsten så småningom konfronteras med är olika försök att omorganisera verksamheten. Övertygelsen om att man genom omorganisering kan utveckla ett bättre, billigare eller mer ändamålsenligt socialt arbete har varit mycket stark bland lokala beslutsfattare. Samtidigt har få saker varit omgivna av en sådan skepsis. Luttrade socialarbetare, desillusionerade projektmakare

Åke Bergmark är professor i socialt arbete vid Mittuniversitetet, Östersund. Tommy Lundström är professor i socialt arbete vid Stockholms universitet. och mer erfarna kommunpolitiker kan alla få någonting trött i blicken när nya organisationsförändringar förs på tal. En vanlig uppfattning är att »organisationer kommer och går, men problemen bestårı. Sett i ett längre tidsperspektiv kan vi trots allt konstatera att vissa grundläggande organisatoriska drag inom det kommunbaserade sociala arbetet varit relativt beständiga under hela 1900-talet. Det gäller till exempel det faktum att socialt arbete är organiserat under kommunala politiska nämnder - något som gör att svenska socialarbetare, jämfört med kollegor i de flesta andra

1 Undersökningen är finansierad av FAS, Forskningsrådet för arbetsliv och socialvetenskap. 
länder, arbetar närmare det politiska systemet (Lundström 1993).

Organisationsförändringar kan genomföras på olika sätt, vissa med stora åthävor och som en följd av tydliga politiska beslut, andra mer stegvis och i det tysta (Pettigrew \& Fenton 2000). Ett exempel på det förra är introduktionen av så kallade beställarutförarmodeller i svenska kommuner under 1990-talet (Montin 2002). Här föregicks förändringarna av en intensiv debatt och av relativt välartikulerade planer för vad som skulle göras. Det viktigaste exemplet på en mer successiv och - med avseende på professionell och politisk intention - ickeexplicit organisatorisk trend, är otvivelaktigt den rörelse mot ökad specialisering som kunnat iakttas i svensk socialvård under de senaste decennierna (Bergmark \& Lundström 1998, Eriksson \& Karlsson 1989). Här har utvecklingen skett mer i det dolda och, åtminstone delvis, i strid med uttalade politiska direktiv.

Att ange vilka organisatoriska utvecklingsdrag som varit mest omfattande eller genomgripande under en viss tidsperiod låter sig inte utan vidare göras. Trots detta är det dock möjligt att peka ut den ökade graden av specialisering inom individ- och familjeomsorgen som en av de mest genomgripande, likriktade och långvariga trenderna inom svenskt socialt arbete under de senaste 20 åren. De samlade kunskaperna om denna utveckling och hur den påverkat arbetets innehåll är emellertid mycket blygsamma. Ur ett professionellt perspektiv är detta anmärkningsvärt, då graden av och formerna för specialisering inte bara reser frågor om vilken kompetens som krävs för yrket, utan också definierar professionella domäner av olika karaktär och räckvidd.

I föreliggande artikel skall vi med utgångspunkt från ett rikstäckande material närmare granska vilka uttryck för specialisering som återfinns inom socialtjänstens individ- och familjeomsorg och hur dessa kan relateras till genomförda organisatoriska förändringar. Vår avsikt är att återspegla specialiseringens olika former, diskutera dess orsaker och tolka de rörelser vi kan iaktta i termer av ändrade förutsättningar för socialarbetarprofessionen och för klienterna. Avslutningsvis behandlar vi hur organisationsförändringar sprids inom socialt arbete.

\section{Socialt arbete: integrering eller specialisering?}

När förarbetena till den socialtjänstlag som, om än i reviderad form, fortfarande gäller publicerades på 1970-talet så framhölls det integrerade sociala arbetet som en ledstjärna. Så kallad funktionsuppdelning borde förekomma i så liten utsträckning som möjligt och »onödiga kompetensgränser bör suddas ut« (prop. 1979/80:1 s. 397). Dessa ställningstaganden grundades i det förordande av en helhetssyn som genomgående präglade arbetet med lagen. Helhetssynen ansågs innebära ett »...avståndstagande från symtomtänkande» och »...en strävan att finna samlade lösningar på den enskildes eller gruppens totala sociala problem « (SOU 1974:39 s. 350-351). Under inflytande av radikala forskare och debattörer på den internationella arenan avvisades specialisering som ett ensidigt och perspektivlöst sätt att betrakta och ta sig an sociala problem (se 
t. ex. Specht \& Vickery 1977). I Storbritannien var det framförallt i kölvattnet efter den så kallade Seebohm-rapporten i slutet av 1960-talet som idéer om integrerade arbetsformer fick fotfäste. Argumentationen liknar mycket den som fördes i Sverige några år senare. Framväxten av en generalistkompetens sågs som en nödvändig förutsättning för eller naturlig konsekvens av en tillämpad helhetssyn (Meyer 1976, Brieland et al. 1980). Överfört till det praktiska arbetet innebar det att socialarbetaren skulle tillägna sig ett brett spektrum av kunskaper och färdigheter och kunna hitta lösningar som berörde ett flertal samhälleliga sfärer. En hårt driven specialisering ansågs oförenlig med detta synsätt.

Begreppet helhetssyn hade således en stark ställning i såväl lagstiftning som socialarbetardiskurs och kom därmed att tolkas inte bara som ett sätt att analysera verkligheten, utan också som en princip för organisering (Bergmark 1998). Det fanns två grundläggande idéer bakom en organisering byggd på begreppet helhetssyn. Den första tog sin utgångspunkt i att man skulle se till den enskilda klientens eller familjens hela situation i stället för att dela in klienterna och deras problem i olika kategorier. Därmed skulle man undvika en onödig stigmatisering och klienterna behövde dessutom inte besöka flera olika socialarbetare. Den andra idén rörde det geografiska området. Ett fullgott socialt arbete innebar inte bara att socialarbetarna skulle känna sina klienter väl, utan också bostadsområdet. Man skulle inte bara arbeta med manifesta sociala problem utan också motverka problemalstrande mekanismer i närmiljön. Uppsökande och förebyggande arbete blev viktiga begrepp och kom att stå för ett sätt att föra det sociala arbetet närmare verkligheten (se t. ex. Pettersson 1986).

Idéerna fick också en motsvarighet i hur det sociala arbetet faktiskt organiserades. På de flesta håll utgick man från en geografisk indelning, där socialtjänsten delades upp distriktsvis i sociala servicecentraler eller socialkontor, som vart och ett hade att svara för ett visst geografiskt område. Vissa funktioner, som t. ex. alkoholmottagning, kunde ligga centralt och inom socialkontoren kunde också förekomma en viss specialisering, men i huvudsak skulle alla socialarbetare arbeta med alla typer av klienter och alla typer av sociala problem.

De förväntningar som väcktes under arbetet med Socialtjänstlagen om ett radikalt annorlunda och samhällsförändrande socialt arbete kom dock aldrig att infrias. Frågor om generalistkompetens, specialisering och lokal förankring har dessutom mer eller mindre försvunnit ur debatten eller kommit att diskuteras med helt andra förtecken. ${ }^{2}$ Den faktiska utvecklingen har också, som tidigare påpekats, gått i helt motsatt riktning än vad som förordades i 1970-talets lagstiftning. Renodlade generalister har blivit ovanliga i takt med att särskilda enheter för barn- och ungdom, missbruk och socialbidrag ersatt tidigare integrerade lösningar (Bergmark \& Lundström 1998).

2 Förhållandet mellan specialiserat och integrerat socialt arbete (specialisation versus generic practice) utgör dock under 1980-talet en del (om än begränsad) av den akademiska diskussionen, åtminstone i Storbritannien (se Challis \& Ferlie 1988). 
Om vi anlägger ett inte alltför långt perspektiv på den svenska diskussionen om det sociala arbetets specialisering kan vi konstatera: i/ den har förflyttats från att vara en fråga relativt högt upp på den politiska och professionella dagordningen till att knappast ägnas något intresse, ii/ tidigare föreställningar om att en högt driven specialisering stod i vägen för ett radikalt socialt arbete har i det närmaste helt försvunnit (eller möjligen är det så att i takt med att idéerna om ett radikalt socialt arbete avmattats så har tankarna om ett områdesförankrat, samhällsförändrande arbetssätt också fått stryka på foten).

\section{Forskningsläget}

En inte oväsentlig del av forskningen om socialt arbete i Sverige har bedrivits med organisationsteoretiska förtecken. Utifrån teorier om människobehandlande organisationer (Hasenfeld 1983) och ofta med inspiration från så kallad nyinstitutionell organisationsteori (Johansson 2002a, Powell \& DiMaggio 1991) har ett flertal forskare närmat sig socialtjänsten. Fokus har då riktats mot sådant som klientiseringsprocesser, organisationernas ansträngningar att anpassa sig till omgivningens krav och förväntningar, betydelsen av maktstrukturer samt professionalisering av det sociala arbetet. Ett visst intresse har också visats för nya organisationsformer, särskilt i spåren efter 1980- och 1990-talens privatiseringsvåg och försöken att implementera marknadsmodeller i socialt arbete (se Blom 1998, 2004, Lundström \& Sunesson 2000, Levin 1998, Wiklund i detta nummer).
Mot bakgrund av detta är det slående hur få ansträngningar som gjorts i syfte att ta fram övergripande kunskap (som går utöver fallstudier av enskilda organisationer) om hur det sociala arbetet faktiskt är organiserat och vad som styr organiseringen. Det finns några få undantag. När det gäller institutionsvård för missbrukare och för barn och unga har det gjorts några undersökningar som kunnat visa på effekterna av 1980- och 1990-talets privatiseringar, samma sak gäller för äldreomsorgen (se Sallnäs i detta nummer och Johansson 2002b). När det gäller kommunernas individ- och familjeomsorg bidrog det så kallade Socialtjänstprojektet till kunskap om hur organiseringen såg ut i några kommuner på 1980talet, före den stora specialiseringsvågen (Mossberg 1984, Pettersson 1986). I slutet av 1980-talet kunde Eriksson och Karlsson (1989) visa att redan då var den integrerade organisationsformen under starkt tryck. Själva har vi kunnat peka på att integrerade organisationer ytterligare trätt tillbaka fram till mitten av 1990-talet (Bergmark \& Lundström 1998). Under senare tid har Björn Blom (2004) på basis av en fallstudie i en svensk kommun diskuterat och kritiserat specialiseringens konsekvenser för socialt arbete.

Ser vi till den internationella litteraturen finner vi också där att väldigt litet intresse ägnats åt att empiriskt söka fastställa hur det sociala arbetet faktiskt är organiserat. Trots relativt omfattande sökningar i tillgängliga databaser verkar det vara närmast omöjligt att återfinna vetenskapliga artiklar som bygger på generaliserbara data och övergripande analyserar hur socialt arbete är organiserat eller vad som bestämmer 
dess organisatoriska särart. ${ }^{3}$ I England och övriga Europa kan man dock återfinna en vetenskaplig diskussion om effekterna av New Public Management på socialvårdens organisering och på socialarbetarprofessionens villkor (se t. ex Harris 1998, Otto \& Schnurr 2000). Med detta viktiga undantag har inte forskningen om det sociala arbetets organisatoriska villkor nått särskilt långt. Något tillspetsat verkar intresset för det sociala arbetets övergripande organisering vara begränsat, trots att det närmast betecknas som en självklarhet att socialt arbete är en omgivningsberoende profession, där just organisering spelar stor roll för praktiken.

Söker vi mer specifikt efter artiklar om specialiserat och integrerat socialt arbete, går det dock att återfinna en del studier. Flera forskare har till exempel diskuterat varför intresset för integrerat socialt arbete blev relativt kortvarigt (Challis \& Ferlie 1988, Hugman 1991). En del menar att ett integrerat arbetssätt i huvudsak representerade en politiskt vänsterdriven återvändsgränd och att övergången till ett mer specialiserat arbetssätt var en förutsättning för en nödvändig kompetenshöjning (Challis \& Ferlie 1988). Man kan också hitta något enstaka exempel på forskare som jämfört effekterna av specialiserat arbetssätt med integrerat (Fuller \& Tulle-Winton 1996).

3 Sökningar har genomförts på Social sciences citation index, Social services abstracts, ERIC, Sociological abstracts med olika kombinationer av sökord som specialization, integration, generic, social work, social service, organisation, organisation theory.
Vi kan sammanfattningsvis konstatera att studier som empiriskt beskriver och analyserar det sociala arbetets organisering på övergripande nivå i stort sett saknas, och att frågor om specialisering och generalistkompetens mer eller mindre är avförda från dagordningen. Samtidigt råder det enighet bland forskare som intresserat sig för frågorna om att socialt arbete är en organisationsberoende profession, där omgivningen - dess regler, normer och förväntningar och dess sätt att forma de yttre villkoren - är betydelsefull för de professionellas yrkesutövning och för relationerna mellan socialarbetare och klient (Lundström \& Sunesson 2000).

Med den här artikeln avser vi att i några grundläggande avseenden täcka kunskapsluckor på området. De data som presenteras bygger på en undersökning av det sociala arbetets organisering i 100 svenska kommuner. Vi vill ge en bild av hur socialtjänstens individ- och familjeomsorg är organiserad med avseende på specialisering inom missbrukarvård, barnavård och försörjningsstöd samt hur organisationsstrukturerna kan förklaras. En ur organisationsteoretiskt perspektiv central fråga är hur och under vilka villkor organisationsförändringar sprids. Med hjälp av institutionell teori, skall vi diskutera vilken roll strukturella faktorer, idéspridning och professionella aktörer kan ha för att påverka organisationsförändringar i ett fält där den tekniska kärnan är svag och där utvärderingar av arbetets effekter är en bristvara (Johansson 2002a, Powell \& DiMaggio 1991). Avslutningsvis skall vi diskutera specialiseringens tänkbara effekter för socialarbetare och klienter. 


\section{Specialiseringens former}

Specialisering inom socialt arbete kan ta sig många olika uttryck. Utgångspunkten kan vara en uppdelning av arbetet utifrån funktion, klientgrupp, metod eller annan form av renodling. Drivkraften kan vara att åstadkomma rent administrativa förbättringar och/eller att förtäta den professionella kompetensen på särskilda områden (Fuller \& Tulle-Winton 1996). Stora, sammansatta organisationer som socialtjänsten erbjuder dessutom en mängd olika nivåer för specialisering och tillika en ansenlig spännvidd när det gäller skilda arbetsuppgifter.

Inom delar av organisationsteorin görs ofta en grundläggande åtskillnad mellan horisontell och vertikal specialisering (alternativt horisontell och vertikal differentiering) (Abrahamsson \& Andersen 1996, Mintzberg 1983). Horisontell specialisering beskriver i vilken utsträckning anställda i en organisation ansvarar för ett mindre antal arbetsuppgifter. I organisationer med hög horisontell specialisering är olika uppgifter åtskilda från varandra och fördelade på särskilda enheter eller på enskilda anställda. Vertikal specialisering går tillbaka på styr- och beslutsformer i organisationerna. Graden av vertikal specialisering betraktas som hög om styrningen av arbetet är tydligt centraliserat och underordnade i huvudsak har verkställande funktioner, något som kännetecknar s.k. hierarkiska organisationer.

I denna artikel behandlas i huvudsak olika uttryck för horisontell specialisering inom individ- och familjeomsorgen. Formerna för detta är emellertid många och ingenting som omedelbart låter sig fångas i tillgängliga teoretiska kategorier. För att klargöra vad vi menar med specialisering och för att illustrera vilka olika varianter som förekommer så finns det anledning att föra ett resonemang om vilka former av organisationsuppdelning som kan inordnas under begreppet. Vi förekommer härmed vår dataredovisning till viss del, men vill ändå peka vilka varianter vi under undersökningens genomförande stött på:

1. Funktionell specialisering: Organisatorisk avskiljning av huvudområden med utgångspunkt från klientgrupp eller problematik. Exempel: arbete med missbruk skiljs från socialbidrag och barnavård.

2. Intern specialisering: Organisatorisk uppdelning inom respektive huvudområde utifrån mer avgränsade klientgrupper. Exempel: Upprättande av särskild ungdomsgrupp inom den sociala barnavården, eller särskild grupp för arbetslösa ungdomar inom försörjningsstöd.

3. Införande av särskilda (behandlings)enheter: Exempel: Öppenvårdsmottagningar och familjeterapigrupper. Baseras till skillnad från 1 och 2 inte på uppdelning av klientgrupper eller sociala problem, utan på organisatorisk särart eller tillkomst av nya arbetsmetoder och arbetssätt. Här inkluderas också tillkomst av nya "stödfunktioner", exempelvis en grupp för rekrytering av familjehem och kontaktpersoner.

4. Införande av enheter för utredning och klientsortering: Exempel: Mottagningsgrupper och särskilda utredningsenheter. Baseras inte heller på uppdelning 
av ansvar för olika klientgrupper utan är ett medel för att kunna kategorisera klienter i olika grupper. Här inräknas också uppgiftsseparering inom ramen för beställar- utförarmodeller.

5. Personburen specialisering inom organisatorisk enhet: Enskilda anställda inom en enhet specialiserar sig, enligt följande varianter:

a. På olika klientgrupper eller sociala problem

b. På olika arbetsuppgifter som utredningar eller familjehemsrekrytering.

c. På olika metoder, som lösningsfokuserat arbete

Kategorierna ät inte ömsesidigt uteslutande. Kombinationer är i själva verket mycket vanliga och gränserna för hur långt en verksamhet kan specialiseras är svåra att fastställa. Vi kan också anta att motiven bakom dessa skilda former för specialisering varierar, liksom vilken typ av övrig organisatorisk inramning som befrämjar särskilda modeller. Vidare måste de beteckningar vi använder förstås i ljuset av den praxis som råder. "Funktionell specialisering" är med andra ord ett uttryck för indelning enligt de huvudfunktioner som man i svenska kommuner vanligtvis identifierar när det gäller det sociala arbetets praktik och inte det enda tänkbara sättet att skilja olika funktioner från varandra. Det betyder att funktionell specialisering i praktiken handlar om att särskilja ett visst område (t. ex. barnavård) från övriga delar av individ- och familjeomsorgen. Det är också i förhållande till dessa tankestrukturer som underordningen av »intern specialisering« skall förstås.

\section{Tillvägagångssätt}

De data som redovisas är hämtade från det s.k. IFO-projektet, där ansvariga för individ- och familjomsorgen i 100 svenska kommuner intervjuats och där olika typer av skriftligt material insamlats. Kommunerna är valda slumpmässigt bland dem som har mellan 13000 och 65000 invånare (totalt 145 kommuner i landet) och materialinsamlingen genomfördes under 2001 och 2002. De största och minsta kommunerna i riket ingår således inte. Det främsta motivet (vid sidan av de rent forskningsekonomiska) till att utesluta de förstnämnda är att vi sökt undvika dem som separerats i kommundelar eller annan geografisk uppdelning av socialtjänsten. Detta eftersom delar av våra analyser förutsätter användning av registerdata som inte finns tillgängliga på mindre enheter än kommun. De minsta kommunerna, sådana som på basis av invånarantalet kan förväntas ha färre än tio socialarbetare, har heller inte inkluderats i studien. Genom att utesluta dessa erhålls ett urval som storleksmässigt är relativt homogent, vilket inneburit en fördel i datainsamlingen och analysarbetet då artefakter och tolkningsproblem som uppstår på grund av alltför stora variationer i organisationernas eller befolkningsunderlagens storlek kunnat hållas under kontroll. Urvalet har en bred spridning på de bakgrundsfaktorer och utfallsdata som vi arbetat med och inkluderar kommuntyper som förorter, industristäder, medelstora städer samt medelstora kommuner i landsbygd. Undersökningens resultat är med andra ord generaliserbara inom detta spektrum, medan eventuella specifika storstadsoch glesbygdsmönster inte fångas in. 
Samtliga kommuner har besökts av intervjuare, som träffat verksamhetsansvariga inom olika delar av individ- och familjeomsorgen. I flera fall har intervjuarna följt upp besöken med telefonsamtal för komplettering av främst olika sifferuppgifter. Intervjuarna har arbetet med fyra instrument, ett för vardera barn/ungdom, socialbidrag och missbruk samt ett övergripande.

\section{En tydlig specialiseringstrend}

I en studie av metoder och organisationsformer under mitten av 1990-talet kunde vi konstatera att trenden mot ökad specialisering redan då gått relativt långt. I hälften av de tillfrågade enheterna bedrevs missbruksarbetet i en eller flera specialiserade enheter, medan motsvarande andel för den sociala barnavården var nära 60 procent. Mest långtgående var specialiseringen inom försörjningsstöd, där det fanns särskilda enheter för socialbidrag i 86 procent av kommunerna (Bergmark \& Lundström 1998). Här kunde alltså konstateras att den integrerade, områdesbaserade organisationsform som förordades i förarbetena till Socialtjänstlagen, var relativt ovanlig ett drygt decennium efter lagens införande. Jämför vi med Erikssons och Karlssons (1989) utredning från slutet av 1980-talet så var andelen kommuner som då hade särskilda enheter för socialbidrag ca 50 procent för landet som helhet och omkring 60 procent för kommuner med 15000 - 100000 invånare. Mycket av det övriga arbetet inom individ- och familjeomsorgen bedrevs vid den tiden inom icke-differentierade behandlingsgrupper.
Vuxenenheter (för vuxna med missbruk eller psykiska problem) fanns i ca 30 procent och barn- och familjegrupper i ca 25 procent av kommunerna (intervallet 15000 - 100000 invånare). Noterbart är också att när kommunerna själva i det materialet fick ange i vilken riktning den senaste omorganiseringen på området gått så svarade mer än hälften "ökad specialisering", att jämföras med sju procent för motsatsen.

Går vi över till den aktuella studien kan vi konstatera att utvecklingen fortsatt i samma riktning. ${ }^{4}$ Fördelningen redovisas i Tabell 1.

Skillnaderna mellan de olika områdena är påtaglig. Mest långtgående är alltjämt specialiseringen på socialbidragsområdet. I bara tre av hundra kommuner kommer klienterna i kontakt med en helt integrerad verksamhet, medan motsvarande siffror för barnavård- och missbruk är omkring tio av hundra. Under flera år diskuterades om handläggning av socialbidraget borde skiljas från det behandlingsarbete som utförs inom ramarna för barnavårds- och missbruksarbetet (se SOU 1977:40). Denna separering av ekonomin tycks i dag i praktiken vara genomförd i de allra flesta kommuner, om än på ett annat sätt och med andra förtecken än vad man tänkte sig under 1970och 1980-talet.

För alla tre verksamhetsområdena gäller att den genomsnittliga "generalistkommunen« är betydligt mindre (20 000 invånare) än den genomsnittliga ıspecialistkommu-

4 Sammansättningen av kommuner/undersökningsenheter i de olika studierna gör jämförelser över tid en aning osäkra. Erikssons \& Karlsson underökning hade högre representation av storstäder/stadsdelar än föreliggande studie. 
nen " (30 000 invånare). Specialisering hänger alltså, föga förvånande, ihop med kommunstorlek. De praktiska möjligheterna och de upplevda behoven att specialisera tycks helt enkelt öka med invånarantalet. Det är värt att påminna att våra resultat $\mathrm{i}$ detta avseende inte är generaliserbara till riket. Om de minsta kommunerna inkluderats i denna studie hade sannolikt en större andel haft integrerad organisation. Detta uppvägs till viss del av att vi inte heller har med de största kommunerna. Med tanke på befolkningens fördelning på små och stora kommuner råder det emellertid knappast någon tvekan om att den absoluta majoriteten av personer som kommer i kontakt med individ- och familjeomsorgen stöter på en specialiserad organisation, där de måste sorteras till rätt enhet innan de kan presentera sitt problem.

I de följande avsnitten skall vi mer i detalj beskriva organisatoriska särdrag inom de tre huvudområdena.

\section{Socialbidrag - mottagning och klientsortering}

I handläggningen av ekonomiskt bistånd finns sedan länge två dominerande former för specialisering av arbetet: mottagningsgrupper och förenklad handläggning. Mottagningsgrupper bygger på idén om att hanteringen av nya ärenden bör standardiseras och att de arbetsuppgifter som förekommer i samband med detta (hänvisa till andra former av ekonomiskt stöd osv.) kräver en särskild kompetens (se Minas 2005 för en diskussion av mottagningsgrupper och Byberg 2002 för diskussion av olika organisationsformers effekter). I vissa fall är mottagningsgrupperna exklusivt inriktade på ansökningar om socialbidrag, i andra fall tar man emot alla som vänder sig till individ- och familjeomsorgen. Förenklad handläggning innebär att vissa ärenden, vanligtvis med "mer uppenbara» löpande socialbidragsbehov, hanteras av särskilda handläggare och övriga ärenden av en annan grupp. Inte sällan vilar ansvaret för den förenklade handläggningen, ofta kallad sådant som SOFT eller EGT, på personal med en lägre formell utbildning medan socionomerna handhar mer sammansatta ärenden (för en bakgrund till uppkomsten av förenklad handläggning, se Bergmark 2000). Ett uttalat syfte bakom denna uppdelning är ofta

\section{Tabell I.}

Andel kommuner med integrerad arbetsgrupp, integrerad arbetsgrupp med personbunden specialisering respektive särskild specialiserad enhet, procent $(n=100)$.

\begin{tabular}{lccc}
\hline & Barnavård & Försörjningsstöd & Missbruk \\
\hline Integrerad arbetsgrupp & 8 & 3 & 10 \\
Integrerad, personburen & 7 & 5 & 12 \\
specialisering & 85 & 92 & 78 \\
Specialiserad enhet & & & \\
\hline
\end{tabular}

Åke Bergmark \& Tommy Lundström: En sak i taget? Om specialisering inom... 
att koncentrera det professionella kunnandet på fall som kräver mer av professionell kompetens. Ett minst lika viktigt motiv, men mindre vanligt i den officiella retoriken, har sannolikt varit att spara pengar.
I Tabell 2 redovisas hur mottagningen av nya ärenden var organiserad i de 100 kommuner vi studerade. En första reflektion är att variationen är betydande och att ingen enstaka lösning dominerar. Vanligast är

\section{Tabell 2.}

Hur mottagningen av nya ärenden är organiserad. Procent ( $n=100)$.

\begin{tabular}{lc}
\hline Mottagningsgrupp enbart för ekonomiskt bistånd & 26 \\
\hline Mottagningsgrupp med ekonomiskt bistånd + annat & 13 \\
$\begin{array}{l}\text { Mottagningen upprätthålls av särskilda handläggare som } \\
\text { en begränsad del av deras arbetsuppgifter }\end{array}$ & 18 \\
Samtliga handläggare turas om att ta emot nya klienter & 15 \\
Samtliga handläggare tar emot på vissa tider & 22 \\
På annat sätt & 4 \\
\hline
\end{tabular}

\section{Tabell 3.}

Förekomst av förenklad handläggning. Procent ( $n=100)$

\begin{tabular}{lc}
\hline - särskild grupp (SOFT/EGT el. dyl.) & 42 \\
- förlagt på ordinarie handläggare & 22 \\
- nej & 36 \\
\hline
\end{tabular}

\section{Tabell 4.}

Innebörd i senaste omorganisation på socialbidragsområdet. Procent ( $n=100)$.

\begin{tabular}{lc}
\hline Specialisering genom inrättande av särskild sektion för ek. bistånd & 30 \\
Intern specialisering av uppgifter (ungdomar, långvariga m.m.) & 14 \\
\hline Inrättande av mottagningsenhet & 4 \\
Övertagande av ansvar för ek. bistånd från andra delar av IFO & 3 \\
Ändrade rutiner för nybesök/mottagningsfunktion & 8 \\
\hline Integrering genom sammanslagning av sektioner & 4 \\
Överflyttning av ansvar för ek. bistånd till andra delar av IFO & 3 \\
Förstärkta personella/ekonomiska resurser & 12 \\
Minskade personella/ekonomiska resurser & 3 \\
Övrigt & 15 \\
\hline
\end{tabular}


dock att funktionen är specialiserad såtillvida att man inrättat en mottagningsgrupp som enbart tar emot klienter som ansöker om ekonomiskt bistånd. Slår vi samman denna kategori med nästföljande finner vi att ungefär fyra av tio kommuner har valt att organisatoriskt avskilja mottagningsfunktionen. Av en följdfråga framgick dessutom att i drygt hälften av de mottagningsgrupper som också behandlade annat än ekonomiskt bistånd så fanns det en "grupp i gruppen" som enbart sysslade med socialbidrag, vilket innebär att specialiseringsaspekten ytterligare förstärks. I två tredjedelar av de kommuner som hade en mottagningsgrupp bestod också denna av mer erfarna och kvalificerade handläggare jämfört med övriga handläggare av socialbidrag (förenklad handläggning undantagen). Som en motvikt kan dock konstateras att närmare fyra av tio kommuner förlägger ansvaret på mottagningen på samtliga handläggare som arbetar med socialbidrag, dvs. de har valt att inte specialisera funktionen.

Av Tabell 3 framgår att förenklad handläggning förekommer $\mathrm{i}$ en majoritet av kommunerna. ${ }^{5}$ Specialisering inom ramen för en särskild grupp är ungefär dubbelt så vanligt som att man fördelar ansvaret på ordinarie handläggare. Ser vi till kriterierna för vilka ärenden som överförs till den förenklade handläggningen finner vi, av svaren

5 Andelen (64 procent) är exakt lika hög som den vi fann i vår studie av metoder och organisationsformer i mitten av 1990-talet. Påpekas bör att den studien bygger på ett annat urval och därför inte fullt ut kan jämföras med resultaten från IFO-projektet. på en följdfråga, att »löpande ärenden där försörjningsproblematiken är stabil över tid" och »löpande ärenden där dessutom inga andra insatser är aktuella» är ungefär lika frekventa. I stort sett överallt utnyttjas icke-socionomer för arbetet, men vanligtvis under ledning av eller i samarbete med socionomer.

Ett mer direkt uttryck för åt vilket håll utvecklingen är på väg får vi om vi tittar på innehållet i de organisationsförändringar som gjorts på socialbidragsområdet. Ungefär en tredjedel av kommunerna hade omorganiserat under de senaste två åren och den genomsnittliga (md) tidpunkten låg fyra år bakåt i tiden. I Tabell 4 framgår vilken typ av förändring det handlade om. I särklass vanligast var en ökad specialisering i form av att en ekonomieller socialbidragssektion inrättades, där socialbidragen tidigare handlagts tillsammans med missbruk och/eller barn- och familjevård. Intern specialisering genom "grupper i gruppen" med ansvar för särskilda klientkategorier var också förhållandevis frekvent, medan inrättande av mottagningsenhet respektive övertagande av socialbidragshandläggning från missbrukrespektive barn-/familjesektioner var mer sällsynt. Slår vi samman de fyra första kategorierna kan vi konstatera att drygt hälften av de organisationsförändringar som genomförts på området handlar om specialisering. En motsatt rörelse hittar vi i första hand i alternativen som handlar om sammanslagning av sektioner samt överflyttning av ansvar för socialbidrag till andra delar av individ- och familjomsorg. Dessa uttryck för integrering återfinner vi endast i sju procent av fallen. 


\section{Vuxna missbrukare - specialisering mot öppenvård}

Missbrukarvården bedrivs till övervägande del inom ramen för specialiserade enheter. Graden av specialisering i dessa enheter kan variera. Generellt innebär beteckningen "missbruksenhet" (48 procent) en högre grad av specialisering än "vuxengrupp" (17 procent). I de senare inryms i vissa fall också stöd åt människor med en psykiatrisk problematik och/eller familjeproblem där barn inte finns med i bilden. Ett annat sätt att beskriva specialiseringen på området är att ta fasta på i hur hög utsträckning ansvaret för ekonomiskt bistånd för de klienter som är aktuella i verksamheten »ligger kvar" på missbruksenheten/vuxengruppen. Ett kvarstående ansvar kan då tolkas i termer av mindre specialisering. Våra data visar att 17 procent av samtliga kommuner har kvar ett i det närmaste totalt ansvar för socialbidragshandläggning för "sina» klienter inom ramen för missbruksarbetet och att arbetet med detta i genomsnitt upptar en tredjedel (md) av den totala arbetstiden.

Ett uttryck för intern specialisering är också ett särskiljande av utredande och behandlande funktioner. Detta är inte särskilt vanligt, bara sex procent av kommunerna har en mer radikal åtskillnad mellan myndighetsutövning och behandling/insats inom ramen för en beställar- utförarmodell. Ytterligare fyra procent har skiljt ut handläggningen av tvångsärenden enligt LVM och lagt ansvaret för dessa på en särskild utredningsenhet.

Betydligt vanligare är att öppenvården av missbrukare ges någon form av egen organisatorisk inramning. Av de sammanlagt
78 kommuner i materialet som angivit att de hade öppenvårdsverksamhet hade en klar majoritet - 85 procent - inrättat ett så kallat öppenvårdsteam. Professionellt bör öppenvårdsteamen betraktas som ett uttryck för specialisering med avseende på uppgift. Samtidigt innebär de emellertid ofta en öppning mot verksamheter utanför socialtjänsten och ett mer eller mindre institutionaliserat samarbete med exempelvis landstinget. Det innebär inte bara en tät samverkan med andra yrkesgrupper, utan också att gränserna för individ- och familjeomsorg/socialtjänst i många fall blir svårare att fastställa mer precist.

För att få ett grepp om mer aktuella utvecklingsdrag kan vi se på de organisationsförändringar som genomförts inom missbrukarvården i de studerade kommunerna. Börjar vi med tidpunkten för den senaste organisationsförändringen, så framträder ett område präglat av organisatorisk instabilitet. I genomsnitt (md) låg den senaste förändringen två år tillbaka i tiden och mer än tre fjärdedelar hade omorganiserat under en femårsperiod.

Av Tabell 5 framgår att inrättandet av en särskild sektion för missbruk utgör den enskilt vanligaste förändringen. Andra uttryck för ökad specialisering finner vi i särskiljande av utredning och behandling (nio procent) och i intern specialisering av specifika uppgifter (fyra procent). Till specialisering bör också överflyttning av uppgifter till andra delar av IFO räknas (innebär framför allt att ekonomisektioner tar över ansvar för socialbidrag från missbruksenheter). Sammantaget fångar dessa kategorier upp drygt 40 procent av de organisationsförändringar som genomförts. $\mathrm{Om}$ 
vi därtill lägger satsning på öppenvård och inrättande av nya behandlings- och boendeenheter ökar andelen till mer än 60 procent. Vad vi återfinner förhållandevis litet av, är tecken på en ökad integrering av arbetsuppgifter. Sammanslagning av olika sektioner och övertagande av uppgifter (främst socialbidrag) från andra sektioner förekom i 14 procent av kommunerna.

\section{Social barnavård - utredning och öppenvård}

Det vanligaste sättet att organisera den sociala barnavårdsverksamheten är i barnoch familjegrupper. Beteckningarna kan skilja sig åt, men sådana enheter finns i 67 procent av kommunerna. I en femtedel av kommunerna har man dessutom specialiserat sig ytterligare genom att inrätta särskilda ungdomsgrupper. Till barn- och familjegrupperna och till ungdomsgrupperna kommer barnavårdsanmälningar från allmänheten och andra myndigheter och det är hit man vänder sig om man vill ha hjälp med en kontaktfamilj eller liknande. Det är i dessa grupper som lejonparten av utrednings- och behandlingsarbetet utförs. Den organisatoriska huvudprincipen utgörs med andra ord av att man sorterar klienterna efter klientgrupp eller typ av sociala problem: a/ barnfamiljer med andra sociala problem än rent ekonomiska och b/ ungdomar med olika typer av sociala problem.

När man organiserar verksamheten i form av en barn- och familjegrupp och/eller ungdomsgrupp förekommer det ytterst sällan att man hanterar socialbidrag parallellt med behandlings- och utredningsverksamheten. Bara fem av kommunerna handlägger det ekonomiska biståndet för de familjer de har kontakt med. Om man bortser från de, oftast små, kommuner som har en helt integrerad organisation förefaller det vara så att den sociala barnavården i praktiken skiljts från socialbidragshanteringen.

\section{Tabell 5.}

Innebörd i senaste omorganisation inom missbrukarvården. Procent ( $n=100)$

\begin{tabular}{lc}
\hline Specialisering genom inrättande av särskild sektion missbruk & 22 \\
Intern specialisering av uppgifter (narkotika, mottagning m.m.) & 4 \\
\hline Särskiljande av utredning och behandling & 9 \\
Satsning på öppenvård, enhet inrättas, resurser ökar & 1 I \\
Nya behandlings- boendeenheter inrättas, spec. resursförstärkningar & 10 \\
Överflyttning av uppgifter till andra delar av IFO & 6 \\
Integrering genom sammanslagning av IFO:s sektioner & 9 \\
Övertagande av uppgifter/ärenden från andra delar av IFO & 5 \\
Behandlings- eller boendeenheter läggs ned, specifika resursminskn. & 3 \\
\hline Övrigt/ej svar & 21 \\
\hline
\end{tabular}

Åke Bergmark \& Tommy Lundström: En sak i taget? Om specialisering inom... 
Inom ramarna för barn- och ungdomsenheterna drivs ofta specialiseringen längre, genom personburen uppdelning av arbetsuppgifter. Det är mycket vanligt att man i en sammanhållen grupp har personal som specialiserar sig på utredningsarbete, familjehemsfrågor osv. I drygt tjugo procent av kommunerna har man skiljt ut utredningsarbetet till särskilda organisatoriska enheter (i två fall inom ramen för en så kallad beställar- utförarenhet). Renodlade beställar/utförarmodeller är alltså ovanliga, medan det är relativt vanligt att man har en särskild grupp för att hantera utredningsverksamheten.

Vid sidan av kärnfunktionerna i barnoch familjegrupper, ungdomsgrupper och utredningsenheter, finns i de allra flesta kommunerna (88 procent) andra typer av verksamheter på barnavårdsområdet. Oftast är dessa "övriga verksamheter" olika typer av öppenvårdsmottagningar för barnfamiljer och ungdomar, där man specialiserar sig på någon särskild klientgrupp genom att verksamheten avskiljs från den mer formella kärnan av barnavårdsarbetet. Liksom för missbrukarvården gäller att öppenvården ibland bedrivs i nära samarbete med andra myndigheter, t. ex. med barnhälsovård och skola. Under rubriken "övriga verksamheter" inryms också särskilda enheter för så kallad hemma-hosverksamhet eller hemma-hos-terapi, dvs. olika former av behandlingsverksamhet som utförs i familjen.

Ser vi på tidpunkt för senaste organisationsförändring så visar det sig att den i genomsnitt (md) låg tre år tillbaka och omkring 70 procent av kommunerna hade omorganiserat under en femårsperiod. Också inom barnavården tycks omorganisationerna göras ofta, även om förändringstakten inte verkar fullt så snabb som på missbruksområdet.

Som framgår av Tabell 6 är trenden mot ökad specialisering mycket tydlig och till och med något starkare än på missbruksområdet. De fyra första kategorierna representerar olika former av specialisering. Sammantaget kan nära 70 procent av de

\section{Tabell 6.}

Innebörd i senaste omorganisation inom social barnavård. Procent ( $n=100)$.

\begin{tabular}{lc}
\hline Specialisering genom inrättande av särskild enhet & 18 \\
Intern specialisering av uppgifter & 14 \\
Ny behandlingsenhet tillskapas & 19 \\
\hline Tillskapande av utredningsenhet & 17 \\
Integrering genom sammanslagning av enheter & 7 \\
Integrering av uppgifter & 7 \\
Nedläggning behandlingsenhet & 1 \\
Överflyttning av uppgifter till andra delar av ifo & 1 \\
Övrigt/ej svar & 16 \\
\hline
\end{tabular}


senast genomförda omorganisationerna ses som funktionell specialisering, intern specialisering (exempelvis i form av inrättande av en ungdomsgrupp eller utredningsenhet) eller (vanligast) att man startar en ny behandlingsenhet utanför barnavårdens kärnområden (t.ex. enhet för hemma-hosarbete eller öppenvårdsmottagning). Tillkomsten av nya öppenvårds- och behandlingsenheter är troligen den tydligaste och mest anmärkningsvärda (åtminstone när gäller styrka) specialiseringstrenden inom den sociala barnavården. Mer väntat är att funktionell specialisering-dvs. inrättandet av särskilda enheter för barnavård - liksom tillkomsten av fler utredningsenheter, fortsätter.

\section{Vad styr graden av specialisering?}

Även om rörelsen mot en ökad specialisering är entydig finns det stora variationer kommunerna emellan när det gäller graden av specialisering. I fråga om funktionell specialisering - dvs. inrättande av särskilda enheter för barnavård, missbrukarvård respektive ekonomiskt bistånd - har utvecklingen dock gått så pass långt att vi idag kan tala om en homogenisering av den organisatoriska strukturen. Integrerade modeller tenderar att försvinna och i dagsläget har nära 80 procent av kommunerna särskilda enheter på samtliga områden.

Intern specialisering av uppgifter och satsning på enheter som arbetar med specifika klientgrupper och metoder är andra tydliga trender i materialet, även om formerna och förändringstakten varierar mellan olika områden. I socialbidragsarbetet handlar det om förenklad handläggning och mottagningsgrupper, i missbrukar-och barnavård om öppenvård och särskiljande av utredning och behandling.

Vi har pekat på att kommunstorlek är en faktor av betydelse för funktionell specialisering. I tidigare analyser har vi också visat att personaltäthet har ett positivt samband med olika uttryck för specialisering (Bergmark \& Lundström 2004). Frågan är dock vilka andra strukturella och organisatoriska villkor som samvarierar med hög specialiseringsgrad? Betyder exempelvis demografiska förhållanden eller indikatorer på socioekonomiska svårigheter i kommunerna någonting? Vilket inflytande har arbetsbelastning och ärendemängd?

I syfte att kunna besvara denna typ av frågor skall vi med hjälp av logistisk regressionsanalys undersöka vilka faktorer som samvarierar med specialisering. Från att tidigare ha behandlat de olika verksamhetsområdena separat, byter vi nu fokus och försöker i stället beskriva den samlade graden av specialisering i de individ- och familjeomsorgsorganisationer vi studerat. Rent tekniskt innebär detta att vi skapar en dikotom variabel där de organisationer som inrättat särskilda enheter för samtliga tre verksamhetsområden och som dessutom har inrättat en särskild utredarfunktion på något område räknas som höggradigt specialiserade. I materialet är det 39 kommuner som uppfyller dessa krav.

I analysen får "höggradig specialisering" utgöra beroende variabel. I ett första steg prövar vi den mot ett antal oberoende variabler som på skilda sätt beskriver viktiga kommunala särdrag. Detta görs i form av

Åke Bergmark \& Tommy Lundström: En sak i taget? Om specialisering inom... 
bivariata analyser. En grupp av variabler utgörs av omständigheter som $i$ andra sammanhang visat sig betydelsefulla för omfattningen av socialtjänstens insatser och som direkt eller indirekt beskriver "problembelastning". I vårt fall är detta andel arbetslösa utan arbetslöshetsersättning, skattekraft, andel ensamstående män 18-39 år, andel ensamstående kvinnor med barn, andel alkoholrelaterade dödsfall, andel utomnordiska invandrare, andel stöldbrott samt brott mot person. Av dessa etablerar endast andel ensamstående kvinnor med barn $(\mathrm{p}=0,032)$ samt andel stöldbrott $(\mathrm{p}=0,004)$ signifikanta samband med höggradig specialisering. Brott mot person uppvisar också ett visst samband $(\mathrm{p}=0,086)$. Vidare har vi prövat sambanden mot totalbefolkning och mot politisk majoritet ${ }^{6}$, där endast det förra uppvisade ett $-i$ allt väsentligt väntat - samband $(p=0,006)$. Avslutningsvis fann vi ett tillika väntat samband mot personaltäthet ${ }^{7} \mathrm{i}$ individ- och familjeomsorgen $(\mathrm{p}=0,003)$.

Tolkningen av dessa samband är inte helt enkel, bl. a. mot bakgrund av att man kan misstänka att flera av dem hänger ihop sinsemellan. Därför finns det skäl att pröva dem i en multivariat modell. Uppsättningen oberoende variabler utgörs i detta andra steg av andel ensamstående kvin-

6 Variablerna som testats är "stabil socialistisk majoritet" respektive "stabil borgerlig majoritet». Stabil står för att majoritetsförhållandet skall ha stått sig över två på varandra följande val.

7 Personaltäthet är ett relativt mått som beskriver antalet heltidsanställda (deltider omräknade) i relation till befolkningens storlek. nor med barn, andel stöldbrott, brott mot person, totalbefolkning och personaltäthet, dvs. variabler som etablerade någon form av samband ovan. I syfte att närmare kunna beskriva sambandens karaktär har vi trikotomiserat dessa variabler i jämnstora delar där den första delgruppen (referenskategorin) samlar den tredjedel som har lägst värden och där den sista tredjedelen har de högsta värdena.

Av Tabell 7 framgår att sambanden för andel ensamstående kvinnor med barn i kommunerna samt andel brott mot person i befolkningen försvinner i den multivariata analysen. Andel stöldbrott kvarstår däremot något överraskande med en mycket klar signifikans. Sambandet är inte alldeles lättolkat, men om stöldbrott skall ses som en "problem-« eller «efterfrågevariabel« med betydelse för individ- och familjeomsorg så är det i första hand i förhållande till barn- och ungdomsvård. Unga människor står för en betydande del av registrerade stöldbrott och ungdomar med omfattande socialtjänstkontakter har ofta erfarenheter av sådana brott. Vad i detta som driver eller på annat sätt hänger samman med specialisering saknar vi underlag att uttala oss om. Möjligen kan man föreställa sig att hög arbetsbelastning på barn- och ungdomsområdet gör ansvariga politiker särskilt angelägna om att upprätthålla en hög kompetens i utredningsförfarandet och att vägen dit uppfattas gå över en långt driven specialisering.

Noterbart är också att befolkningsstorlek framträder som mindre betydelsefullt än i den bivariata analysen. Visserligen kan alltjämt ett visst positivt samband iakttas, men det är endast större kommuner som 
avviker på ett sätt som närmar sig signifikans. Däremot kvarstår sambandet med personaltäthet som oförändrat starkt. Här erbjuder sig ett par olika tolkningar. För det första kan en hög grad av differentiering i verksamheten leda till en ökning av personal därför att vissa typer av stordriftsfördelar går förlorade (t.ex. fler mellanchefer). För det andra är det möjligt att se inrättandet av specialiserade enheter som ett uttryck för prioriteringar eller resursmässiga satsningar (se Bergmark \& Lundström 2004).

\section{Diskussion och sammanfattning}

Sammanfattar man de organisationsförändringar som skett på de tre verksamhetsområdena kan konstateras att den funktionella

Tabell 7.

Samband mellan kommunala särdrag och höggradig specialisering av individ- och familjeomsorgen. Logistiska regressioner $(n=100)$.

\begin{tabular}{|c|c|c|}
\hline & Oddskvot & $p=$ \\
\hline \multicolumn{3}{|c|}{ Brott mot person: } \\
\hline - lågt & 1 & \\
\hline - medel & 0,32 & 0,144 \\
\hline - högt & 0,31 & 0,163 \\
\hline \multicolumn{3}{|c|}{ Ensamstående kvinnor med barn: } \\
\hline - låg & I & \\
\hline - medel & 1,36 & 0,685 \\
\hline -hög & 0,785 & 0,777 \\
\hline \multicolumn{3}{|c|}{ Stöldbrott: } \\
\hline - låg & I & \\
\hline - medel & 12,42 & 0,002 \\
\hline - hög & 8,29 & 0,017 \\
\hline \multicolumn{3}{|c|}{ Befolkningsstorlek: } \\
\hline - mindre & I & \\
\hline - medel & 1,85 & 0,367 \\
\hline - större & 4,02 & 0,057 \\
\hline \multicolumn{3}{|c|}{ Personaltäthet: } \\
\hline - låg & I & \\
\hline - medel & 4,30 & 0,041 \\
\hline -hög & 7,97 & 0,005 \\
\hline
\end{tabular}

Åke Bergmark \& Tommy Lundström: En sak i taget? Om specialisering inom... 
specialiseringen gått mycket långt vid en jämförelse med mitten av 1980-talet. Det är bara (med något undantag) i de minsta kommunerna som två eller tre av verksamhetsområdena barnavård, missbrukarvård och socialbidragsarbetet är samorganiserade. Den helt dominerande organisationsformen innebär att de tre områdena är separerade. Våra data begränsar sig som framgått till kommuner av mellanstorlek. Man kan rimligen utgå från att de kommuner som är för stora för att ingå $i$ vårt urval i hög utsträckning är specialiserade, medan motsatsen gäller för de minsta. Det faktum att den större delen av befolkningen bor i kommuner som är lika stora eller större än de som ingår i vårt urval - nära 90 procent av Sveriges befolkning bor i kommuner med fler än 13000 invånare - innebär att de allra flesta klienter kommer i kontakt med en socialtjänst med långtgående specialisering och att en klar majoritet av socialarbetare inom socialtjänsten arbetar specialiserat. Helhetssyn i organisatorisk mening, vilket faktiskt fortfarande utgör en bärande princip i lagstiftningen, är med andra ord $\mathrm{i}$ praktiken nästan helt avskaffad.

Om man jämför specialiseringens konkreta uttrycksformer på de tre verksamhetsområdena är bilden relativt sammansatt. Det finns vissa likheter om man jämför barnavård med missbrukarvård. I bägge fall finns oftast en »kärnenhet» $i$ form av en barn- och familjegrupp respektive vuxengrupp (beteckningarna kan skilja sig åt). I en del kommuner har man skiljt ut utredningsverksamheten från behandlingsarbetet - mer vanligt inom barna-än inom missbrukarvården. Vid sidan av denna grundorganisation hittar vi ofta öppenvårdsmot- tagningar av olika slag. Inom missbruksområdet arbetar inte sällan dessa tätt ihop med sjukvården. På barnavårdsområdet utgörs öppenvården ofta av mottagningar dit ungdomar, föräldrar och /eller familjer kan komma för rådgivning, men här finns också enheter som sysslar med specialiserat behandlingsarbete av olika slag. Det är med andra ord möjligt att identifiera vissa genomgående mönster i organisationsförändringarna inom barna- och missbrukarvården under de senaste åren. Dit hör fortsatt specialisering, fler öppenvårdsenheter och tillkomst av utredningsenheter. Samtidigt är utvecklingen allt annat än enhetlig och lösningarna skiljer sig från kommun till kommun. Bilden är i dag på det hela taget mer sammansatt och komplicerad än vad ett motsvarande nedslag skulle ha gett vid handen under 1970-talet eller tidigare.

Organiseringen av socialbidragshanteringen är möjligen det som förändrats mest under 1980- och 1990-talet. Det är numera mycket ovanligt att socialarbetare inom socialtjänsten arbetar med försörjningsstöd och barnavård eller missbrukarvård. Avskiljningen av socialbidragshantering från behandlings- och utredningsarbetet inom barnavård och missbrukarvård - en fråga som debatterades mycket under 1970och början av 1980-talet - tycks nu genomförd i de flesta kommuner. Renodlingen av mottagningsfunktioner och den höga förekomsten av förenklad handläggning innebär att ekonomiskt bistånd också internt är ett område präglat av specialisering.

Det brukar sägas att omorganisationer har formen av pendelrörelser där organisatoriska lösningar tenderar att gå från den ena extrema riktningen till den andra. Inom 
socialtjänsten skulle man således pendla mellan integrering och specialiseringen. Svaret på integreringens problem blir specialisering och tvärtom och så fortsätter det i cykliska modeväxlingar. Vi vill ifrågasätta ett sådant antagande. Mycket talar för att den integrerade organisering av det sociala arbetet som genomfördes i spåren av socialtjänstlagen snarast skall ses som en historisk parentes. Redan när det sociala arbetet började ta organisatorisk form i skiftet mellan 1800- och 1900-talet, gjordes det med en tydlig uppdelning (också lagstiftningsmässigt) i barnavård, nykterhetsvård och fattigvård. I större kommuner fanns dessutom ytterligare uppdelningar och historiskt sett har sedan skett än fler uppspjälkningar av verksamheter. Från 1960-talet började denna funktionsuppdelning ifrågasättas, först under rubriken familjevårdsprincipen (hela familjen skulle behandlas tillsammans) sedan utifrån begreppet helhetssyn (Lundström 1993). Vad som hänt under 1980- och 1990-talet kan delvis ses som en återgång till den gamla funktionsprincipen. Gamla institutionaliserade och över tid mycket stabila mönster tycks alltså spelat stor roll för de former som socialtjänstens omorganisationer tagit sig, något som $\mathrm{i}$ organisationsteoretisk litteratur brukar beskrivas som typiskt för människobehandlande organisationer (Lundström \& Sunesson 2000).

Men under 1980-talet uppträder också helt eller delvis nya former av specialisering som vissa kommuners uppdelning i utredande och behandlande verksamhet, socialbidragshanteringens åtskillnad mellan klientkategorier och de olika öppenvårdsverksamheter som vuxit fram. Sett i ett långt historiskt perspektiv förefaller det som om den samhälleliga organiseringen av de uppgifter som nu ingår i socialtjänstens individ- och familjomsorg utmärks av en gradvis ökande professionalisering (i meningen inkluderande av nya fält i en professionell sfär) och specialisering, med en kort parentes av integrerings- och generaliststävanden under 1970- och början av 1980-talet.

Vad vi har att göra med tycks alltså dels vara en del organisatoriska moden och mer eller mindre kortlivade idéer eller trender vilka tar sig organisatorisk form. Här återfinns sådant som beställar/utförarmodeller och olika typer av öppenvårdssatsningar. Specialisering som sådan kan däremot knappast betraktas som ett kortlivat mode. För att lösa problem av olika slag eller för att svara upp mot omgivningens förväntningar tycks specialisering snarast vara en institutionaliserad strategi inom socialvården. Krävs det ökad kompetens i utredningsarbetet eller satsningar på ungdomsvård är det organisatoriska svaret att skapa en ny enhet. Specialisering tycks sällan ifrågasättas utan fungerar som en naturlig respons på omgivningens krav på nytänkande (se Jacobsson 2002 för en diskussion av organisatoriska trender inom offentlig förvaltning).

Om vi väljer att analysera individ- och familjomsorgen som ett organisatoriskt fält kan vi konstatera att det består av det som i organisationsteoretisk litteratur brukar kallas institutionaliserade organisationer (Lundström \& Sunesson 2000). Med det menas att organisationerna i hög grad är underordnade omgivningens regelverk och kulturellt förankrade normer för hur arbetet skall utföras. Detta omgivningsbe-

Åke Bergmark \& Tommy Lundström: En sak i taget? Om specialisering inom... 
roende är bl. a. avhängigt att individ- och familjeomsorgen (liksom t.ex. skolan) inte har en tydligt identifierbar teknisk kärna. Det är med andra ord inte givet vare sig hur arbetet skall utföras eller hur resultaten skall värderas (Meyer \& Rowan 1977, Johansson 2002b).

Vilka är då de drivkrafter som kan förklara den ökande specialiseringen och de specifika former den fått under 1980- och 1990-talet? Det är närmast ogörlig uppgift att peka ut alla faktorer som påverkat förändringarna (särskilt de lokala). Vi begränsar oss till att peka på de fyra viktigaste: (1) politiska förändringar, (2) påverkan från professionen, (3) ändrade ekonomiska villkor samt (4) förändrad "efterfrågan«.

En första mer grundläggande förändring på politikens område är de successivt ökade möjligheterna för kommunerna att själva bestämma över sina organisationsformer (Bergmark 2001). I organisationsteoretisk litteratur menar man ofta att en av de viktigaste faktorerna för att åstadkomma organisatorisk isomorfi eller likformighet är statens möjlighet att genom tvingande åtgärder som lagstiftning reglera organisatoriska fält (DiMaggio \& Powell 1983). Vad som hänt i Sverige sedan 1980-talet är att statens regleringar av kommunal verksamhet minskat. Kommunerna har fått större möjligheter att själva bestämma över sitt sätt att utföra och organisera sin verksamhet, vilket lett till att socialtjänstens organisering idag uppvisar större olikheter än tidigare. Det är ett viktigt skäl till att individ- och familjeomsorgen kan ge ett ganska oöverskådligt intryck. Även om det finns vissa tydligt identifierbara mönster och även om man i vissa grundläggande drag kan hitta principer för organiseringen som till och med går tillbaka till förra seklets början, är det ändå så att socialtjänsten uppvisar betydligt mindre organisatorisk enhetlighet än tidigare.

Ett tydligt politiskt inflytande på individoch familjeomsorgen finner vi i introduktionen av olika typer av marknadsmodeller och öppningen mot privata lösningar. Tillskapandet av särskilda utredningsenheter är otvetydigt inspirerat av marknadsidéer om fördelar med uppdelning i beställnings- och produktionsenheter. Men här kompliceras bilden av att ett särskiljande av utredning från behandlingsverksamhet också har stöd i professionellt förankrade idéer om det positiva (av etiska och andra skäl) med att skilja myndighetsutövning från annat socialt arbete (se Pettersson 1988). Till det kommer en långvarig, delvis vetenskapligt och delvis massmedialt förankrad, kritik mot brister i kompetens när det gäller barnavårdsutredningar, där svaret blivit expertis i form av särskilda enheter. Det är med andra ord en förhållandevis komplex uppsättning idéer på den nationella arenan som påverkat den lokala organiseringen. På samma sätt tycks det förhålla sig med idéer om satsningar på särskilda klientgrupper eller metoder i socialt arbete. Olikheter på lokal nivå visar att när de nationellt förankrade idéerna och den lokala praktiken möts så finns det utrymme för förhållandevis stora organisatoriska variationer (se Ekermo 2002, Johansson 2002a, Røvik 2000).

De svenska kommunernas ekonomiskt utsatta läge är sannolikt en bidragande faktor till genomförda organisationsförändringar. Som en följd av 1990-talets ekonomiska kris och strukturella förändringar 
i inledningen av 2000-talet, brottas många kommuner idag med en svår ekonomisk situation (SOU 2001:79, Svenska Kommunförbundet 2002). Vad som sker när kommunernas ekonomi allvarligt försämras är att uttryck som sparmål och kostnadsmedvetande lyfts fram som operativa begrepp. Specialisering framstår sannolikt då som en naturlig strategi för att, i Tayloriansk anda, höja produktiviteten och få ut mer socialt arbete per satsad skattekrona. Förändringarna på socialbidragsområdet bär tydligt sådana förtecken. Ekonomiska hänsyn har högst troligt också drivit på tillskapandet av öppenvårdsenheter och så kallat särskilt boende för missbrukare som mindre kostnadskrävande alternativ till institutionsvård. Forskning som visar på dåliga resultat när det gäller institutionsvård av missbrukare har ytterligare underlättat en sådan växling (Oscarsson 2000).

Det förändrade trycket i form av ökad "efterfrågan« märks tydligast på barnavårdsområdet. Även om statistiken är osäker talar det mesta för att det skett en ökning av antalet barnavårdsanmälningar under senare år. Likaså har trycket från det juridiska systemet ökat bland annat till följd av förändrad lagstiftning. Det krävs helt enkelt mer av socialtjänstens barnavård, det visar sig inte minst genom att antalet ungdomar som placeras $\mathrm{i}$ institutionsvård och $\mathrm{i}$ fosterhem ökat under 1990-talet. Ungdomsbrottslighet och kriminalitet har också fått en mer framträdande roll i den politiska debatten (Andersson \& Lundström 2002, Lundström \& Vinnerljung 2001). Här kan man sannolikt hitta bidragande förklaringar till att inrättandet av särskilda ungdomsenheter har varit så vanligt under senare år.
Vi har pekat på ett antal faktorer som kan ha bidragit till ökad specialisering och de former som den fått. De data som presenterats här ger emellertid inte möjlighet att mer ingående besvara frågor om hur idéer sprids eller hur ekonomiskt tryck och variationer i "efterfrågan" växlas in i organisationsförändringar samt hur dessa förändringar i sin tur påverkar det faktiska klientarbetet. För det krävs mer forskning med andra metoder. Samtidigt vill vi understryka att studier av förhållandet mellan idéer och organisationsförändringar är viktiga, inte minst ur ett teoretiskt perspektiv (se Johansson 2002a), men naturligtvis också för att kunna svara på frågor om hur "styrbart" det sociala arbetet är.

Avslutningsvis några ord om specialiseringens effekter för klienterna och det sociala arbetet. Vad man med viss säkerhet kan utgå från är att de organisationsförändringar som skett de senaste åren har gjort systemet mer komplicerat för klienterna. Det bör rimligen vara så att det idag är svårare att veta vilken enhet man skall ta kontakt med eftersom det helt enkelt finns fler än tidigare. För att komma in systemet krävs dessutom oftast att relationen inleds med någon form av sorteringsprocedur. Det skall vägas mot eventuella fördelar av större expertis och att det för klienten faktiskt kan upplevas som en vinst att inte vara beroende av en enda socialarbetare som "vet allt» om ens liv. Det vore därför välmotiverat med forskning som söker belysa specialiseringens effekter ur ett klientperspektiv.

När man söker analysera fördelar och nackdelar med specialisering finns det en tendens att göra det på ett alltför abstrakt 
plan. Var skall man exempelvis börja när man skall särskilja en integrerad organisering från en specialiserad? I Sverige är det inte ovanligt att man kontrasterar ett integrerat områdesbaserat arbetssätt som det gestaltade sig i början av 1980-talet mot alla andra former av specialisering (Blom 2004). I Storbritannien, där specialiseringen av socialt arbete gått längre, förefaller man i första hand intressera sig för effekterna av en ytterligare nedbrytning av socialt arbete (Fuller \& Tulle-Winton 1996). Vi har svårt att tänka oss att man i allmänhet kan svara på om specialisering är bättre än ett integrerat arbetssätt. Alla sådana analyser kräver ju för övrigt att man utgår från någon form av samhällelig arbetsdelning. Även de som vill slå ett slag för ett integrerat arbetssätt som det såg ut på svenskt 1980-tal verkar ta för givet att exempelvis skolsocialt arbete skall bedrivas avskiljt eller ser arbetsdelningen mellan hälsovård och socialt arbete som mer eller mindre naturlig (se Blom 2004). Det behövs naturligtvis forskning om effekterna av de senaste årens stora organisationsförändringar. Viktigt är dock att förståelsen av vad som är att betrakta som specialisering uppdateras och att man i kommande analyser förmår hantera den komplexitet och differentiering på olika nivåer som kännetecknar den aktuella utvecklingen.

\section{Litteratur}

Abrahamsson, B. \& Andersen, J. (1996) Organisation: att förstå och beskriva organisationer. Malmö: Liber-Hermod.

Andersson, G. \& Lundström, T. (2002) »Barns och ungas utsatthet i pressen". Socionomen, $\mathrm{nr} 8 \mathrm{del}$ 2, Forskningssupplement nr 14, 21-31.

Bergmark, Å. (1998) Nyckelbegrepp i socialt arbete. Lund: Studentlitteratur.

Bergmark, Å. (2000) "Arbete med socialbidrag - organisation, metoder och insatser". I Puide, A. Socialbidrag i forskning och praktik. Stockholm: Gothia.

Bergmark, Å. (2001) „Den lokala välfärdsstaten? Decentraliseringstrender under 1990-talet». I Szebehely, M (red.) Välfärdstjänster $i$ omvandling. SOU 2001:52, Stockholm: Fritzes.

Bergmark, Å. \& Lundström, T. (1998) "Metoder i socialt arbete». Socialvetenskaplig tidskrift, 5, 291-314.

Bergmark, Å. \& Lundström, T. (2004) „Det sociala arbetets viktigaste resurs? Om omfattningen av personal inom socialtjänstens individ- och familjeomsorg". Socialvetenskaplig tidskrift, 11, 2, 119-135.

Blom, B. (1998) Marknadsorientering av socialtjänstens individ- och familjeomsorg: om villkor, processer och konsekvenser. Umeå: Umeå universitet, institutionen för socialt arbete.

Blom, B. (2004) "Specialisation in social work practice - effects on interventions in the personal social services». Journal of Social Work, 4, 2546.

Brieland, D., Costin, L. \& Atherton, C. (1980) Contemporary Social Work: an Introduction to Social Work and Social Welfare. New York: McGraw-Hill,

Byberg, I. (2002) Kontroll eller handlingsfrihet? En studie av organiseringens betydelse $i$ socialbidragsarbetet. Diss. Stockholm: Stockholms universitet, institutionen för socialt arbete. 
Challis, D. \& Ferlie, E. (1988) »The Myth of Generic Practice: Specialisation in Social Work". Journal of Social Policy, 17, s. 1-22

DiMaggio, P.J. \& Powell, W.W. (1983) »The Iron Cage Revisited: Institutional Isomorphism and Collective Rationality in Organizational Fields". American Sociological Review, 48, s. 147-160.

Ekermo, M. (2002) Den mångtydiga FoU-idén: lokala FoU-enheters mening och betydelse. Örebro: Universitetsbiblioteket.

Eriksson, B. \& Karlsson, P-Å. (1989) Organisationsformer inom socialtiänstens individ- och familjeomsorg. Stockholm: Socialstyrelsen.

Fuller, R. \& Tulle-Winton, E. (1996) „Specialism, Genericism and Others: Does It Make a Difference? A Study of Social Work Services to Elderly People». British Journal of Social Work, 26, 679-698.

Harris, J. (1998) "Scientific management, bureauprofessionalism, new mangerialsm: The labour process of state social work». British Journal of Social Work, 28, 839-862.

Hasenfeld, Y. (1983) Human Service Organizations. New Yersey: Prentice Hall.

Hugman, R. (1991) "Organization and Professionalism: The Social Work Agenda in the 1990s". British Journal of Social Work, 21, 199-216.

Jacobsson, B. (red.) (2002) Organisationsexperiment $i$ kommuner och landsting. Stockholm: Santérus.

Johansson, R. (2002a) Nyinstitutionalismen inom organisationsanalysen. Lund: Studentlitteratur.

Johansson, S. (2002b) Sociala ideella organisatio ner - som kommunerna ser dem: om kommunernas relationer med sociala ideella organisationer. Stockholm: Socialstyrelsen.

Levin, C. (1998) Uppfostringsanstalten: om tvång $i$ föräldrars ställe. Lund: Arkiv.

Lundström, T. (1993) Tvångsomhändertagande av barn - en studie av lagarna, professionerna och praktiken under 1900-talet. Stockholm: Stockholms universitet, Socialhögskolan.

Lundström, T. \& Sunesson, S. (2000) "Socialt arbete utförs i organisationer». I Meeuwisse A., Sunesson S. \& Swärd H. (red.) Socialt arbete en grundbok. Stockholm: Natur och Kultur.
Lundström, T. \& Vinnerljung, B. (2001) »Omhändertagande av barn under 1990-talet«. Szebehely, M. (red.) Välfärdstjänster $i$ omvandling. SOU 2001:52.

Meyer, C. (1976) Social work practice. The changing landscape. New York: Free Press.

Meyer, J.W. \& Rowan, W.R. (1977) "Institutionalized Organizations: Formal Structure as Myth and Ceremony". American Journal of Sociology, 83, s. 341-363.

Minas, R. (2005) Administrating Poverty-Studies of Intake Organiztion and Social Assistance in Sweden. Stockholm: Stockolms universitet, institutionen för socialt arbete.

Mintzberg, H. (1983) Structure in fives: designing effective organizations. New Jersey: Prentice Hall.

Montin, S. (2002) Moderna kommuner. Malmö: Liber.

Mossberg, R. (1984) Socialtjänstens organisering och möjligheter i fyra kommuner. Stockholm: Stockolms universitet, institutionen för socialt arbete.

Oscarsson, L. (2000) "Den socialtjänstbaserade missbrukarvården under 1990-talet: förutsättningar, utveckling och behov«. I Szebehely, M. (red.) Välfärd, vård och omsorg. SOU 2000:38.

Otto, H. \& Schnurr, S. (red.) (2000) Privatisierung und Wettbewerb in der Jugendhilfe: Marktorien tierte Modernisierungsstrategien in internationaler Perspektive. Neuwied: Luchterhand.

Pettersson, U. (1986) Socialtjänsten i praktiken: från mål till verklighet. Stockholm: Skeab.

Pettersson, U. (1988) Vägen ut värderad: om social tjänstens organisation i Eskilstuna. Stockholm: Stockolms universitet, institutionen för socialt arbete.

Pettigrew, A. \& Fenton, E. (red.) (2000) The Innova ting Organization. London: Sage Publications.

Powell, W.W. och DiMaggio, P.J. (red.) (1991) The New Institutionalism in Organizational Analysis. Chicago: University of Chicago Press.

Prop 1979/80:1. Om socialtjänsten. Regeringens proposition.

Røvik, K.A. (2000) Moderna organisationer: trender inom organisationstänkandet vid millennieskiftet. Malmö: Liber.

Åke Bergmark \& Tommy Lundström: En sak i taget? Om specialisering inom... 
SOU 1977:40 Socialtjänst och socialförsäkringstil-

lägg: lagar och motiv. Socialutredningens slutbetänkande.

SOU 1974:39 Mål och medel. Socialutredningens principbetänkande.

SOU 2001:79 Välfärdsbokslut för 1990-talet: slut- betänkande. Kommittén Välfärdsbokslut.

Specht, H. \& Vickery, A. (1977) Integrating social work methods. London: George Allen \& Unwin.

Svenska Kommunförbundet. (2002) Kommunala framtider - en långtidsutredning om behov och resurser till år 2050. Stockholm.

\section{Summary}

\section{On the specialization of Swedish social work}

A phenomenon that every social worker in Swedish municipalities (where the bulk of Swedish professional social work is carried out) will be confronted with is reorganization. Among local decision-makers on different levels there seems to be a strong conviction that reorganization serves as an efficient tool to establish cost-effective and high-quality social work. This article presents some of the results from a research project dealing with the organizational settings and resources of Swedish social work on the municipal level. Social work managers in a representative sample of 100 medium-sized municipalities (of Sweden's 288) have been interviewed face-to-face using an extensive interview manual. Data are analysed with quantitative methods including multivariate analysis. If the organizational changes in the last 20 years are summarized, they can be described in terms of functional specialization, i.e. child welfare, social assistance and social work with substance abusers which were previously organized in an integrated manner are today with very few exceptions specialized, and in many municipalities specialization has gone much further. The organizing of social work on the municipal level also presents far more diversity than before. Some of the organizational changes observed in this study (different types of open care units etc.) might be understood in terms of short-lived fashions or trends, but that is hardly the case for specialization as such. On the contrary, it seems as if specialization is an institutionalized strategy to solve problems of different kinds and to live up to expectations from the environment. The different forms of organizational change in the municipalities can be understood against the background of four factors: political change, professional influence, economic restraints and changed "demand". 